\title{
EDITORIAL
}

\section{In Tribute to Charlie Houston}

\section{From Mechanix Illustrated, January 1947: NAVY Tackles Mt. Everest}

In an epochal 30-day experiment the Navy "climbed" two men "higher" than Mt. Everest-without oxygen. By CAPT. J. H. KORB, U.S. Navy Medical Corps, as told to James Nevin Miller

SCIENCE now has proved that flyers and mountain climbers can reach altitudes of almost six miles, remain normal and alert, and come away none the worse for wearwithout supplemental oxygen ... It is only necessary that they accustom themselves gradually to the decreasing pressures and dwindling oxygen ... For this discovery, of much value in the planning of future upper air explorations, credit goes to a pair of venturesome young men of the $U$. $S$. Navy_Lieut, (jg) Walter S. McNutt, Jr., and Carlton R. Morris, Hospital Apprentice. Under the supervision of Lieut. Cmdr. Charles S. Houston, U.S.N.R., a flight surgeon and authority on mountain climbing, McNutt and Morris tested for an entire month, in Florida, an odd sea-level combination of mountain climbing and airplane flying called "Operation Everest." The men lived in a compression chamber. They "flew" or "climbed" almost six miles without supplemental oxygen and suffered no ill effects. They reached a simulated altitude of 29,025 feet-23 feet higher than the unconquered peak of Mount Everest, the highest mountain in the world... The program's purpose was to study the adaptation of the human body to slowly increasing anoxia, or lack of oxygen. As a result of its findings it may be possible to reproduce artificially the necessary physiological changes in an aviator in order to "acclimatize" him quickly before he reaches the upper air ... Morris and McNutt reached the "altitude" topping Mount Everest, remained there for almost 30 minutes and didn't lose consciousness... The test chamber was really something to see. It was of steel, about 20 feet long and perhaps 10 feet in diameter, with two doors about six feet apart in one end. Technicians and observers who entered the chamber did so by way of a small lock, remaining there until its air was reduced to the same pressure as that of the volunteers; and when they left the process was reversed. The chamber bristled with control appliances and was operated by a 14-man crew of experts ... It was interesting to watch McNutt and Morris as they "climbed" to their

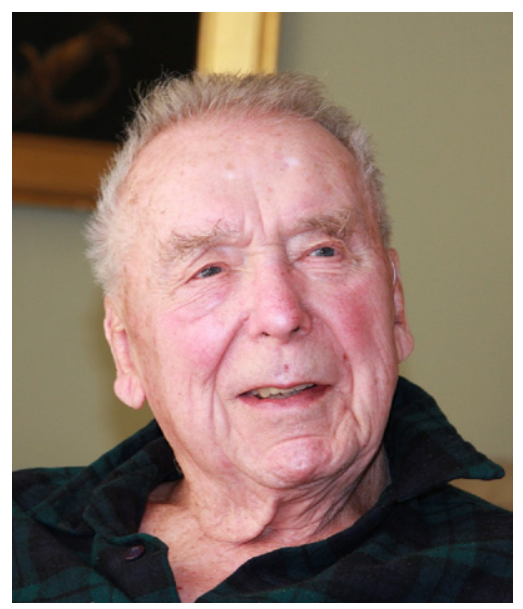

Dr. Charles Houston

record-breaking height of 29,025 feet on the next to the last day. When they reached this height their blue complexions turned to a rather deep purple. (If this sounds a bit wild, let me explain that men start to turn blue in the face after they've been exposed to heights of about 13,000 feet without supplemental oxygen.) At this point they were breathing heavily and looked definitely uncomfortable; but they stayed there without supplemental oxygen for four hours ... Other high altitude physiological studies are sure to follow this initial effort ...

It is with great sadness that the Wilderness Medical Society (WMS) notes the death of Dr Charles (Charlie) Houston in 2009 at the age of 96. Charlie was one of the Founding Members of the WMS and remained actively involved with our organization until age slowed him down. What follows are a few remembrances of Charlie from persons who knew him well. Words never do justice fully to any man or woman, but as we suffer his loss, they can perhaps add a bit of color to his memory, both for those close to him and those who knew of him from afar. As Rob Roach so eloquently pointed out to me in a correspondence, "Charlie was much more than a founding member of the WMS. Before there were thousands of people going to WMS meetings, there were Charlie's meetings at the Yosemite Institute. Before there was a Journal of Wilderness Medicine, there was Charlie with his book Going Higher attempting to edu- 
cate people about high altitude. Before any of us had ever heard of $\mathrm{K} 2$, Charlie was attempting to find a route to the top." I agree with Rob-Charlie was in many ways an innovator, and definitely a force.

To set the stage, the following facts and commentary are adapted from the reporting by Stephen Goodwin in the United Kingdom for the Independent Newspaper. Charlie was born in New York on August 24, 1913. He was introduced to the hills by his parents and at the age of 12 had walked with them from Geneva to Chamonix. While a medical student, he joined the Harvard Mountaineering Club, teaming up with 4 other enthusiasts to form the "Harvard Five." In 1933, he was invited to climb on Mt Crillon, Alaska and a year later participated in an expedition led by his father, Oscar Houston, to make the first ascent of Mt Foraker. During subsequent expeditions, he participated in climbs on such mountains as Nanda Devi and in prospecting the approach to Mt Everest from the Nepal side. During a journey in 1950 he explored the Khumbu valley towards the southern flank of Everest. Prior to this time, expeditions to Everest had always approached from the north in Tibet. Charlie and others camped on the Khumbu glacier and viewed the intimidating icefall that cascades from the Western Cwm. They assessed the icefall to be too hazardous for laden porters and doubted that Everest could be climbed by this route. They were wrong, but they were there.

As a mountaineer, Charlie is most famously associated with K2, giant of the Karakoram and arguably the most difficult of the world's 8000-m peaks. Charlie led 2 expeditions to K2. The first, in 1938, was an acclaimed reconnaissance during which he and Paul Petzoldt became the first climbers to reach "The Shoulder" on the Abruzzi Spur. It had required a supreme effort, wading in deep powder snow. "I felt that all my previous life had reached a climax in these last hours of intense struggle," Houston wrote.

Charlie made studies of "thin air" during the Second World War. Entering the Navy as lieutenant in 1941, after interning at the Presbyterian Hospital in New York, he trained pilots in the effects of hypoxia at combat altitudes. Immediately after the war, Houston persuaded the Navy to let him do further research on volunteers in a decompression chamber. Called Operation Everest, the tests were ostensibly about gaining air combat superiority but were ultimately more interesting to mountaineers, because they showed that with acclimatization, humans would be able to survive briefly at the top of the world. Twenty years later, Houston returned to the subject, directing physiology studies each year from 1967 to 1975 at a laboratory at $5300 \mathrm{~m}$ on Mt Logan in the Canadian Yukon, and re-running a more ambitious version of Operation Everest in 1985.
War service over, Houston returned to K2 in 1953 with a team that included his close friend Bob Bates. Storm and struggle accompanied the team up the Abruzzi Spur; even so, by the beginning of August they were encamped just below The Shoulder and optimistic that the summit was within reach. Just 3 good days were needed. However, foul weather confined them to battered tents. In retrospect, Charlie was philosophical about the 10-day battering at Camp VIII. "Perhaps it is this conquest, conquest of one's self through survival of such an ordeal, that brings a man back to frontiers again and again."

On August 7, as the clouds lifted and the climbers crawled out of their tents, the young geologist Art Gilkey collapsed unconscious in the snow. He had developed phlebitis, with blood clots in his left leg. As both a doctor and climber, Charlie knew there was no chance of getting Gilkey back to Base Camp alive, but there was also no question about whether or not the team would try to save him. Avalanche risk and bad weather delayed them for 3 days, until, as Gilkey's condition worsened, descent became imperative.

In a raging blizzard, with Gilkey wrapped in a sleeping bag and smashed tent, an exhausted and ice-encrusted team began inching him down the mountain. Gilkey had just been lowered over a cliff when one of the climbers, who suffered frostbitten feet, slipped, dragging his rope-mate with him, and dislodging others. Bates thought his end had come. Once off the ice slope, they would all drop hundreds of meters to the glacier below. Amazingly, the 5 hurtling climbers were halted on the lip of the abyss by the strength and superb belaying technique of another team member, who also held the weight of the suspended Gilkey.

Many believe that the critical juncture in Charlie Houston's life came at that moment on August 10, 1953 as he lay unconscious on a narrow shelf high on the Abruzzi Spur. Charlie was coaxed back from the brink of death by Bob Bates, who awakened him and ordered him to climb $50 \mathrm{~m}$ to the shelter of a camp. Bates recalled it thus: "Charlie," I said with the greatest of intensity, looking directly into his eyes, "if you ever want to see Dorcas and Penny (his wife and daughter) again, climb up there right now." By accounts, Charlie then fairly swarmed up the snowy rocks of the cliff.

After being urged back to life by Bates, Charlie had little idea where he was. "What are we doing here?" he kept repeating. Battered and bleeding, the party struggled to the nearby Camp VII, and then 3 of them went to fetch Gilkey, who had been left anchored by 2 ice axes. He had vanished, swept to certain death by an avalanche. It was another 4 days of nightmare descent before the team stumbled gaunt and hollow-eyed into the embrace of their porters. During the descent, Charlie was at times delirious. At a reunion 25 
years later he revealed how close he had come to ending it all above a technically difficult "chimney" pitch. He feared he would knock his friends off the mountain if he fell. "Better jump off to one side and get it over with," he'd thought. "I knelt in the snow and said the Lord's Prayer. Next thing I can remember is being grasped by strong arms and helped into Camp IV."

Charlie never again attempted a high mountain ascent. He ceased climbing and devoted himself to his family, medicine, and human good. A growing family and rural medical practice increasingly filled his time. The years 1957 to 1962 were spent working as an internist in Aspen. He then became Director of the United States Peace Corps for India, an ideal post for someone so devoted to the well-being of his fellow human beings.

Charlie settled into teaching medicine at the University of Vermont and, as we all know, became one of the great authorities on high altitude-related medicine. During his life, he authored K2: The Savage Mountain $;{ }^{1}$ Going High, The Story of Man and Altitude (which became Going Higher: Oxygen, Man and Mountains ${ }^{3}$ ); and Five Miles High (with Robert Bates and Jim Wickwire). ${ }^{4}$

In his last decade, Houston's liberalism reasserted itself publicly and he would stand on a soapbox in Burlington city park railing against the warmongering of George W. Bush and the shameful absence of universal medical care in the United States. He was a man of complex emotions, as revealed in a fine biography by Bernadette McDonald, entitled Brotherhood of the Rope..$^{5}$ In May 2006, Charlie received an honorary doctorate from the University of Colorado. At that time, fundraising was initiated to fully endow the Charles Houston Chair in High Altitude Medicine and Physiology. To date, more than $\$ 550,000$ has been raised toward the long-term goal of a $\$ 2$ million dollar endowment. For more information, and to contribute, please see: http:// www.altituderesearch.org/about/csh.

Now, let us hear directly from some of those who knew him.

\section{From Drummond Rennie, MD, FRCP, MACP}

\section{Deputy Editor, Journal of the American Medical Association, Adjunct Professor of Medicine, Institute for Health Policy Studies, University of California San Francisco}

For nearly 40 years, I have had a photograph of Charlie in my office. I'm looking at him now. He's sitting in the radio shack beside the Arctic Institute's dirt strip at Kluane, in the Yukon, with an old dark blue baseball cap clamped on his grizzled short-cropped hair. He's calmly chatting with Phil Upton who is in the Heliocourier, 100 miles away over the huge massif of Mt Logan.

Two days before Charlie died, I phoned him from my home in Oregon, some 3000 miles away. Robin, his elder son, answered and after Robin and I had spoken for a couple of minutes, he held the phone to Charlie's ear. I could hear Charlie trying to say something we decided later was about my articles on drug companies. "Charlie," I shouted into the phone, "I want you to know you're very, very annoying. And I love you, I really do." I thought I heard a laugh.

In all sorts of ways, that sums it up. From the time I met him, in 1968, to the time he died, Charlie drew me in, encouraged, needled, bullied, cajoled, threatened, and inspired me. In hundreds of phone calls between Burlington and my home in Chicago, he'd have me banging my head against the wall in frustration, promising myself I'd never, ever work with him again. And then he'd turn around and, making good use of his scientific argument and shameless use of his charm, draw me into sometimes reluctant acquiescence. He would listen to my deepest worries about goals, feasibility, safety, and by sharing his own concerns, draw me into his web-a web made up of at least as much emotion as science.

Back in 1968, at a conference in Aspen on lowoxygen, high altitude physiology, Charlie was recruiting for an exciting new project. A few months before, under Charlie's direction from the radio shack, Barry Bishop had led a group of climbers up Mt Logan to set up a temporary research lab at $17600 \mathrm{ft}$ on the summit plateau. They showed that despite the extreme conditions, the lab as a habitable structure was feasible. Now the question was whether research could be done there, and if so, what questions could best be answered.

A week before the Aspen conference, I had returned from studying kidney oxygenation in miners in the central altiplano of Peru, and I was due to return to the Andes to work on long-term hypoxia. But here in Aspen was one of the world's great mountaineers and foremost altitude experimentalists, an icon as well as a hero, urging me to join him to do any number of studies. The project sounded inspired, bold, and thrilling. All I had to do was tell him what studies I wished to do, and help write the grant proposal. And, of course, the next year, 1969 , make the project actually produce. So I signed on and began a relationship that changed my life.

The Mt Logan project, both down by Lake Kluane and up at High Camp, combined all that was best about research and much of what I wanted from being in the mountains. Charlie took care of the daily worry of running a complex and widely spread operation, in difficult and potentially very dangerous terrain, under conditions 
where disparate scientific goals might clash as much as disparate personalities. It became one of the greatest experiences of my life, not merely because of the friends I made, or just because of the grandiose mountains and vast glaciers. It was wonderful because Charlie, the great leader that he was, made it so, because he set the tone: good-humored, efficient, tolerant, self-effacing, and affectionate. He managed the complex logistics and equally complex characters, with firm wit and steady purpose.

One of the project's most productive studies came at the start with the observation that retinal hemorrhages occurred on sudden ascent. The subsequent careful hemodynamic studies on the retinal circulation were a triumph for Regina Frazer and for Charlie. ${ }^{6}$ By the time the entire project closed, I had left, and many of the lead scientists had scattered. Charlie went on to other research projects, meanwhile being the genius who, with his colleagues, set up and maintained the Hypoxia Conferences.

Over 3 years, Charlie and I tried to work together on a book, but eventually I dropped out, baffled by the distance between Chicago and Burlington, the very different phases of our lives, and above all by the disparate view we had of the book's aims and readership. Charlie was proved right by the book's subsequent success, but the split was painful for me, and, I believe, for Charlie. When Going High ${ }^{2}$ came out, and I discovered he had dedicated it to me, I was deeply moved by his generosity.

We sparred often. But he sparred with everyone with whom he worked closely, and perhaps I got on better with him than most. Many of us at some time or other swore blind they'd never work with Charlie again, because he could be so controlling, so unable to give over any imagined reins. But we still would have died for him. When, 10 years ago, Charlie was accused of having falsely claimed to have been the first to describe high altitude pulmonary edema, rather than Herb Hultgren of Stanford, I was delighted to be in a position to leap to his defense. I had been lent Herb Hultgren's diaries, and was able to prove that neither he nor Hultgren claimed to be first to describe the condition, nor the first to show high altitude pulmonary edema could not be due to an effect of altitude on the heart. ${ }^{7}$

For years, as I went into medical editing and could no longer keep up the altitude work, we preserved a distance-perhaps a wary distance. But a year or so ago, Charlie and I had yet another entire day at his home in Burlington, where, 40 years ago, he had once played me a tape the members of his $\mathrm{K} 2$ expedition had recorded in a tent as they licked their wounds immediately after their descent. We went on into the late evening, he in his big chair, I picking my way between the stacks of books. Now, decades later, we hammered away at everything from the precise physical make-up of the Silk Road, Marco Polo's reliability, and Genghis Khan's attitude (right wing), all the way to nitric oxide and the microvasculature, through to the machinations of the pharmaceutical companies, and a single-payer healthcare system. Of course, we had quite a few conversations since, but each one more limited, and, most ominously, each one showing a more resigned, cheerier Charlie. Charlie and I had always liked to engage, and the slow disappearance of that engagement, and the taking on of a simpler, more grateful and less prickly personality was oddly painful.

Now we must all get used to the fact that Charlie, this tremendous presence, this great man, is no longer around. There must be many others like myself who feel the void and wish they could tell Charlie how grateful we are. At least I was given the privilege of telling him, yet again, how annoying he could be, and how much I loved him.

\section{From Phil Powers}

\section{Executive Director, American Alpine Club, Golden, $\mathrm{CO}$}

I know Charlie mostly as a mountain climber. From his leadership on the first ascent of Nanda Devi in 1936the highest mountain ascended until Annapurna was climbed 14 years later-to his expeditions on K2 in 1938 and 1953, Charlie represented the best in climbing.

The seminal moment of Charlie's climbing life came on K2 in 1953. He and his partners decided to put their entire effort into rescuing team member Art Gilkey, who was incapacitated by altitude sickness. They knew that the rescue was not only virtually impossible, but that it would also very likely cost them their lives. The men placed the contract of the belay - the "brotherhood of the rope," as Charlie would so often refer to it-above concern for self. They failed to save Gilkey. But against great odds, they succeeded in bringing each other down alive. Reinhold Messner said, "I have great respect for the Italians who summitted K2 for the first time in 1954, but even greater respect for the Americans and the way they failed in 1953. They were decent. They were strong. And they failed in the most beautiful way you can imagine. This is the inspiration of a lifetime." Their heroic dedication to one another, to staying together and bringing each other down safely, remains an example not only for all climbers, but for all people.

Charlie's vision extended far beyond the mountains. His book Going Higher ${ }^{3}$ was and is the bible of high altitude medicine for the lay reader. Charlie's research 
brought attention to understanding human adaptation to altitude, and is the underpinning of the acclimatization strategies and medical regimens employed today. Charlie was a tireless investigator. His high altitude research on Mt Logan from 1967 to 1979, the Operation Everest high altitude chamber studies in 1946 and 1985, and his founding of the International Hypoxia Symposia are just a few examples. He even tinkered in the family basement with the creation of an artificial heart.

In 2006, I had the opportunity to spend an afternoon in the midst of the surviving members of the iconic expedition to K2. Our purpose was to sustain Charlie's work in high altitude medicine with the University of Colorado's Altitude Research Center and establishment of an endowed chair in Charlie's name. Mostly, however, we assembled to celebrate Charlie. As Streather, Bates, Craig, and Molenaar gathered around Charlie, I witnessed that what Charlie had observed was true. "We entered the mountains as strangers, but we left as brothers."

\section{From Robert Brownie Schoene, MD}

\section{Pulmonary and Critical Care Medicine, Bozeman Deaconess Hospital, Bozeman, MT}

Many individuals make a difference in spite of themselves; others make a difference because of themselves. Charlie Houston made a difference to many people for both reasons. Charlie's near-century of a life has been recounted by many people more eloquent than I, so I will not repeat their laudatory recounting of a remarkable man, but I will offer a few reflections that have evolved over the 35 years that I knew him.

As we all know, Charlie was an extremely bright and perceptive man who could be engaging and charming, as well as inscrutable and irascible. He had two uncanny talents that catalyzed his legend in the histories of both mountaineering and medicine. First, he had brilliant ideas. In fact, some of those ideas were genius. Second, he was able to attract and get commitments from teams of both climbers and scientists, all of whom had the "right stuff" to accomplish what he divined, sometimes in spite of him.

Charlie made an immeasurable difference in my life. My early pursuit of a medical career and passion for climbing happened to overlap. Sometime in the mid1970s, Charlie organized one of several mountain medicine seminars in Yosemite. For what more could I ask? It was there that I began to know and appreciate Charlie (I was too shy to introduce myself), as well as important others such as Noel Odell, Herb Hultgren, and Gil Rob- erts. I gained a sense that there was history and awe in the fellowship that mountains brought to people.

My early academic career coincided with the inception of the Hypoxia Symposia, and the rest is history. I presented my first paper at "Hypoxia" with Charlie sitting right next to me, more pleased that I had finished perfectly at 10 minutes than with my science. I was thrilled to be there, and I owe much to his encouragement. Yet Charlie never kept things simple, and I began to see another side of this complex man. On the first day of Operation Everest II, as we 26 investigators descended on Natick, Charlie was ready to call it all off. In a very heated meeting, Jack Reeves and John Sutton on the spot resurrected what Charlie had been about to disassemble, and what Charlie then went on to lead brilliantly.

Several years later, Charlie asked me to spend a sabbatical year as Research Director in Keystone at the Colorado Altitude Research Institute, an operation of his own creation. I was ecstatic to be offered this honor and opportunity. With my usual naive optimism, I threw myself into a dream job, only to find myself having differences with Charlie, who was 2000 miles away in Burlington. At a meeting in Chamonix that winter, I skied with John Sutton, who had worked for 20 years with Charlie. With some despair, I explained my conflicts with Charlie and asked John what he thought I was doing wrong. John said, "Mate, don't worry. He's always like that and has driven me nuts for years. But I love him anyway."

The subsequent years have caused me not to ponder my plights with Charlie, but to be grateful for the great differences he made to so many. Experiencing Charlie has made me appreciate how important it is for each of us to put aside our idiosyncrasies and realize how much influence we have on young, developing minds and spirits. Charlie challenged himself and was able to share much of his nurturing soul with many of us, inspiring a generation of young physicians, scientists, and mountaineers.

I spoke with Charlie shortly before he died. He seemed glad to hear from me, and with his sharp memory asked how Bozeman was and how my wife, Kim, my older children, and our young child, Kira, were doing. So Charlie, I love you for all of the facets of your heart. You got me started on a professional and personal life linked to the thin air that has enchanted so many of my colleagues and friends, without whom my life would have been much less.

\section{From Peter Hackett, MD}

Director, Institute for Altitude Medicine, Telluride, CO

In the spring of 1975, I was 27 years old and took care of trekkers and climbers who suffered altitude sickness on 
their way to Everest Base Camp, 2 day's journey above my earthen-floor yak hut at 14000 feet in Pheriche, Nepal. I thought about Charlie Houston, who 25 years earlier had been in the first party allowed to explore the Khumbu region and south side of Mt Everest. I often wondered what it must have been like to be the first foreigner in the area. I knew that Charlie had mixed emotions about being the vanguard of the "intrusion of the West" into the Sherpa homeland. For decades, he chose not to return for fear of observing what "progress" had wrought in the land he wished to remember as undisturbed by modernity.

The medical literature on altitude illness was scant, and I was more than curious. From what I could gather during visits to the Shanta Bhawan Hospital library in Kathmandu and with Dr John Dickinson, Charlie was the world's expert, so I wrote to him, detailing my experience with 66 cases of severe acute mountain sickness and HAPE. I received an enthusiastic and helpful reply, and we began a correspondence, and then a relationship akin to father and son, for the next 34 years.

In 1977, I participated in the Mt Logan project. I was awed by the boldness of Charlie's vision. Flying subjects from sea level to the $17500-\mathrm{ft}$ summit plateau of $\mathrm{Mt}$ Logan was risky business. (Most scientists and support staff staged the ascent with a stay at King's Trench camp and then either climbed or flew to the plateau.) Weather was troublesome, flying was dangerous, and logistics were nearly unmanageable. HACE, airplane crashes, and stranded personnel kept Charlie busy and worried all summer. But the operation was successful. Despite the difficulties, Charlie showed that a lab devoted to high altitude medicine could be operated in an extreme environment and be productive. He helped set the stage for subsequent similar projects on Everest and Denali. ${ }^{8}$ Charlie's leadership was inspiring; it was certainly one of his great talents. He chose his team very carefully; he was a master at appraising other's capabilities as well as potential problems, and the resulting group was like a family. No doubt, Charlie could sometimes be gruff, stubborn, and demanding, but the loyalty he inspired worked magic.

Charlie finally returned to Nepal in 1981, and visited base camp during the American Medical Research Expedition to Everest. I received a note from him, sent from Base Camp, while I was at Camp III on my way to the summit. He advised me, "Don't be surprised if you find you don't have the reserves you thought you did" when up very high. I didn't quite know what to make of that. Was he worried about me, or challenging me? A few days later I endured a near-death experience with a fall on the Hillary Step on the way down from the top. Fortunately, his admonition was incorrect.
In 1985, at the age of 72, Charlie headed-up a remarkable project-Operation Everest II. This was a sequel to the famous 1947 Operation Everest, in which he showed that humans could indeed survive a gradual ascent to the altitude of the summit of Mt Everest without supplemental oxygen. For Operation Everest II, he obtained funding, convinced the Army to provide the chamber, organized a talented and diverse crew of more than 20 scientists-featuring John Sutton, Jack Reeves, and Allen Cymerman-and oversaw every aspect of the operation. There were daily obstacles and problems, some of which he created himself. He and others emerged feeling like they had been through a war, but a successful one. This endeavor resulted in more than 35 scientific papers, as well as many book chapters, and was a true landmark in the field of high altitude physiology. ${ }^{9,10}$ For many of the participants, the interactions with Charlie created the richest memories.

Charlie was first and foremost a doctor. He cared about people more than research or science, but he combined these in a way that I have tried to emulate. His exhausting rescue of a sick skier on a cold New Year's Eve night in 1959 above Aspen characterized his compassion and caring, as well as his intellectual curiosity; the rescue resulted in his classic New England Journal of Medicine paper on high altitude pulmonary edema. ${ }^{11}$ Many a day on Denali, I emulated Charlie's action in Aspen, rescuing climbers who also provided intellectual challenges and opportunities for scientific investigation. Charlie's somewhat irascible personality caused him to confront bureaucracy and avoid the medical "establishment" more often than most. While this exacted a certain price, it was a path that appealed to me, and that I also followed. Perhaps having tasted the freedom of the hills, mountaineers do not adjust well to the restrictions of full-time academia. The beauty of Charlie was that he crossed over many times in his career, and so was able to inspire both in the lab and on the mountain.

\section{From Paul S. Auerbach, MD, MS, FACEP, FAWM}

Professor of Surgery, Division of Emergency Medicine, Stanford University School of Medicine, Palo Alto, CA

When I think back on how I came to wilderness medicine, my thoughts are not populated by scenes of mountain peaks, snowfields, and foaming surf, but by individuals-the people, some mentors, some provocateurs, some radical fun-seekers-who were comrades, sounding boards, and conspirators. Compared to many, I was young and so they were older, a few of them already living legends. They were a community, and I was an 
upstart. That's the time in my life when I first encountered Charlie Houston.

The Yosemite Institute held gatherings on mountain medicine. In the late 1970s as a resident in emergency medicine at the University of California, Los Angeles, any excuse was a good one to escape urban Los Angeles and head for the hills. Ed Geehr and I discovered the Yosemite Institute (and Peter Hackett and Brownie Schoene), which held gatherings in glorious Yosemite National Park. The occasion for one visit was mountain medicine, because Ed and I were contemplating creating a book on wilderness and environmental emergencies. We were eager to share our ideas and enthusiasm with some of the greats - John Dill, Herb Hultgen, Charlie Houston, and the like. We questioned them incessantly. They were all tolerant of the young bucks, but gruff Charlie liked to challenge.

"A textbook? Wilderness medicine? I doubt it," Charlie admonished me. "We've already got mountain medicine. It'll be too confusing. There are too many textbooks. Way too expensive. Nobody'll buy it. I don't think it's a good idea." Just reading these words, one might think that Charlie was against the concept. But he had twinkling eyes. He was not trying to discourage me. He was testing my commitment. We compiled the chapters and the rest is history.

Fast forward a few years. I met with Charlie again, this time to get his view on a new organization devoted to wilderness medicine. He was more emphatic than before. He dismissed my idea with a wave of his hand. "Young fellow, whatever for? There are too many societies. Nobody likes to pay dues. It'll never get off the ground." I was indeed still a young fellow compared to Charlie. I turned back and he gave me a wink. I coerced him into becoming a founding member. The rest is history.

It was time to take the WMS to the next level and start the Journal of Wilderness Medicine. This time I knew the routine. I wanted Charlie to shoot me down so that I could confirm that we would have a winner. Without hesitation, he obliged. "Don't do it. Who needs another journal?" So of course we did it, Charlie joined the inaugural Editorial Board and the rest is history.

I came to know Charlie very well, not because I felt obliged, but because I value people who think out of the box and speak their minds. Charlie may be best known for his contributions to mountaineering and high altitude medicine, but all of us in wilderness medicine know that in our specialty he very much earned his stripes, commonly behind the scenes. Sometimes he was irascible and meted out tough love, but it was love all the same, and we could tell and we thrived on it.

\section{From Thomas Hornbein, MD}

Professor Emeritus, Departments of Anesthesiology, and Physiology and Biophysics, University of Washington, Seattle, WA

I first met Charlie when I was 14 . He climbed from the pages of James Ramsey Ullman's High Conquest, ${ }^{12}$ a gripping history of mountaineering, into my boyhood dreams. His expeditions to Nanda Devi in 1936 and K2 two years later were rich fantasy. He and his companions were like mythic heroes to a small boy with a big imagination.

Charlie met me when our paths intersected beside a swimming pool on a hot June day in 1963. The pool belonged to the American ambassador to India, John Kenneth Galbraith. Charlie was the first director of the first Peace Corps group in India. Our team was passing through Delhi on the way home from Everest. I shared with Charlie the tale of our adventure on Everest's West Ridge. His clear pleasure with our accomplishment was seasoned with a wistful speculation about whether it might have been done without the use of supplemental oxygen. I tasted firsthand Charlie's philosophy that mountains should be approached with simplicity and reverence. It was a lesson in humility that was the first of many gifts bestowed by this wise curmudgeon as our friendship evolved over the years.

Charlie was a dreamer with an uncommon ability to transform big visions into big reality-his 1936 and 1938 Himalayan expeditions and the epic, icon K2 expedition in 1953, Operation Everest I and II, the Mt Logan research era, and the biennial Hypoxia meeting, perhaps his greatest legacy to our high altitude research community. Charlie was determined, not wanting for strong views strongly expressed. As his Peace Corp colleague, Bill Moyers, opined in a remembrance to his friend, Charlie could be "ornery, blunt, and sometimes insufferable," yet "he was a deeply moral man and a real patriot." And, one of the most giving, caring persons I have known. The concept Charlie cherished after his team's attempt to get an ailing Art Gilkey down off the mountain at huge risk to themselves was that of "the brotherhood of the rope" (the title of his biography by Bernadette McDonald ${ }^{5}$ ). Though he never climbed another mountain after that trip, the metaphorical rope attached him to many who had the benefit of his loving, caring belay. 
How blessed we are to have known Charlie Houston. Even though our weekly chats must now be in my mind's eye, so much else remains.

\section{From Robert C. Roach, PhD}

\section{Research Director, Altitude Research Center, University of Colorado, Aurora, CO}

I first met Charlie 31 years ago when, as an undergraduate, I sought his advice on a tough choice: volunteer to work on Mt Logan with him, or pursue a National Science Foundation (NSF) grant to study acute mountain sickness on Mt Rainier. Although the NSF project won out, I drove out from the Midwest to meet Charlie, which was the beginning of a relationship that changed my life. Charlie welcomed me, and over the years, my family into his life. We skied together in Aspen, skinny dipped at his retreat in the Adirondacks (my wife Barbara still struggles with the memory), and crossed paths repetitively in beautiful places around the world. Most satisfying of all, "Uncle Charlie," the toughest mountaineer our sons could ever imagine, offered my children a personal barometer for how high they might reach. Much has been written about how Charlie swore off climbing high mountains after the ill-fated $1953 \mathrm{~K} 2$ expedition, but that does not mean that he swore off living a life striving to climb other metaphoric mountains. Each of us who knew him closely will attest that being "driven" by Charlie was not always easy, but for me it proved to be deeply satisfying.

Our first big project together was Operation Everest II. Charlie was in his 70s, and ran that project, along with John Sutton, Peter Wagner, and Jack Reeves, with force and determination. Charlie roped me into helping him create a database of the results from all of the $35+$ studies in the project. We made the database, but it was severely limited by the technology available to relate such disparate pieces of information. This was the first of many ideas and projects worked on by Charlie and me where his vision far exceeded what was technically possible.

Charlie left a huge mark on the world of mountaineering, and on the intersection of mountains and medicine. His book Going Higher ${ }^{3}$ remains the best starting point for understanding how humans relate to high altitude. He had considerable foresight about the need for education about hypoxia, both for professional and lay audiences. In the last few years, Charlie visited Colorado, where students listened carefully to his lessons about the brotherhood of the rope. The experiences and teaching methods that Charlie shared with us inspired many to become better teachers and mentors.
Charlie was a large part of the creation of the Yosemite mountain medicine conferences, which by 1979 had morphed into the International Hypoxia Symposia. Charlie, John Sutton, and Geoff Coates were determined that "Hypoxia" be anything but another dry and boring medical meeting. Through Charlie's genius of bringing people together to think about difficult problems, they designed a meeting where people not only explored cutting edge research related to hypoxia but did so in an environment where they met, ate, and skied together. When John Sutton passed away in 1996, Charlie asked the symposia advisors what they wanted to do with the program, because he did not feel up to continuing it alone. My friend Peter Hackett and I were the only 2 people who said we thought the meeting had run its course and should be allowed to fade away. In Charlie's mind, this somehow made us the perfect candidates to take over the meeting! We did so with trepidation. Twelve years later, "Hypoxia" continues to provide joy and inspiration. In reflection, Charlie was an early proponent of what we now call "translational medicine," with integrative physiology at its core. Because of waning health and logistical problems, Charlie attended his last Hypoxia meeting in 2007. Charlie was rightfully proud in his last few years of what he had helped create for high altitude researchers and clinicians.

Charlie always wanted to know everything that was going on, how the people he knew in the field were faring, and what new breakthroughs were being made. Patience was not his strong suit, and when I would complain in our frequent conversations that I had no major breakthrough to report since our previous conversation, he would remind me that I should not be wasting time talking to an old geezer when I could be working in the lab. Yet among my friends, Charlie was always the one to admonish me to not work too much. He understood and supported the need to get out and enjoy life, so he prodded me to spend more time with my family. He was determined that those dear to him never lose sight of all of life's wonders. And so, I will do my best to follow this advice.

Paul S. Auerbach, MD, MS, FACEP, FAWM Department of Surgery Division of Emergency Medicine Stanford University School of Medicine Palo Alto, CA

\section{References}

1. Houston CS, Bates JH. K2: The Savage Mountain. Guilford, CT: The Lyons Press; 2008.

2. Houston CS. Going High, The Story of Man and Altitude. Burlington, VT: American Alpine Club; 1980. 
3. Houston CS, Harris DE, Zeeman EJ. Going Higher: Oxygen, Man, and Mountains, 5th ed. Seattle, WA: The Mountaineers; 2005.

4. Bates RH, Houston CS. Five Miles High: The Thrilling True Story of the First American Expedition to K2, 2nd ed. Guilford, CT: The Lyons Press; 2000.

5. McDonald B. Brotherhood of the Rope: The Biography of Charles Houston. Seattle, WA: The Mountaineers; 2007.

6. Frayser R, Houston CS, Bryan AC, et al. Retinal hemorrhage at high altitude. N Engl J Med. 1970;282:1183-1184.

7. Rennie D. Herb Hultgren in Peru: What causes high altitude pulmonary edema?-Advances in experimental medicine and biology. In: Roach RC, Wagner PD, Hackett PH, eds. Hypoxia: Into the Next Millenium. Vol 474. New York: Kluwer Academic/Plenum Publishers, 1999:1-22.

8. Houston CS. High Altitude Physiology Study-Collected Papers. Burlington, VT: Queen City Press; 1980.

9. Houston CS, Sutton JR, Cymerman A, Reeves JT. Operation Everest II: man at extreme altitude. J Appl Physiol. 1987;63:877-882.

10. Houston CS. Operation Everest I and II. Studies of acclimatization to simulated high altitude. Respiration. 1997; 64:398-406.

11. Houston CS. Acute pulmonary edema of high altitude. N Engl J Med. 1960;263:478-480.

12. Ullman JR. High Conquest. 